\title{
FLOOD PROFILE STUDY, SQUAW CREEK, LINN COUNTY, IOWA
}

\author{
Prepared by \\ U.S. Geological Survey, Department of the Interior, \\ in cooperation with the City of Cedar Rapids, lowa
}

Open-file Report

June 1968 


\title{
FLOOD PROFILE STUDY, SQUAW CREEK, LINN COUNTY, IOWA
}

\author{
Prepared by
}

U.S. Geological Survey, Department of the Interior, in cooperation with the City of Cedar Rapids, lowa

Open-file Report

June 1968 
Introduction: . . . . . . . . . . . . . . . 1

Description of area ............... 3

study criteria. . . . . . . . . . . . . . . 3

Presentation of results .............. 5

Cited references

ILLUSTRATIONS

Plate 1. Map of Linn County showing location of Squaw

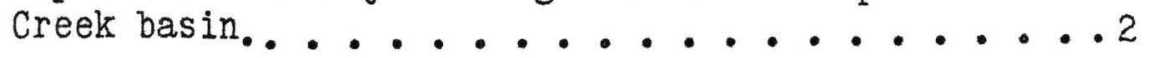

2. Map of Squaw Creek, station 0 to 56 showing inun-..

dation limits and waterway outlines.......11

3. Map of Squaw Creek, station 54 to 129 showing inundation limits and waterway outlines. ......12

4. Map of Squaw Creek, station 127 to 179 showing inundation limits and waterway outlines. . . . .13

Figure 1. Flood profiles and streambed profile, mouth to station 45, on Squaw Creek. .........

2. Flood profiles and streambed profile, station 45 to station 90, on Squaw Creek........ 8

3. Flood profiles and streambed profile, station 90 to station 135, on Squaw Creek........99

4. Flood profiles and streambed profile, station 135 to station 180, on Squaw Creek. ....... 10

\section{TABLE}

Table 1. Water surface elevations, in feel above mean sea level, and mean velocities, in feet per second, for selected floods on Squaw Creek........ 6 
FLOOD PROFILE STUDY, SQUAW CREEK,

LINN COUNTY, IOWA

INTRODUCTION

This report is the result of a cooperative agreement between the city of Cedar Rapids and the U. S. Geological Survey that provides for the collection of hydrologic data by the Geological Survey on small streams in and near the city. The city furnished the large-scale topographic map showing a stream reference line marked off in 100-foot stations and a part of the data on valley cross sections used in the preparation of this report.

The purpose of this report is to show, for an 18,000-foot reach of Squaw Creek, (1) flood-inundation limits for a large flood under present channel and valley conditions, and (2) water-surface profiles for the above flood and for a lesser flood contained in a waterway restricted by two assumed degrees of encroachment. Mean velocities are also given at many places for the selected conditions. The information provided can be useful to State and local agencies involved in floodplain management. 


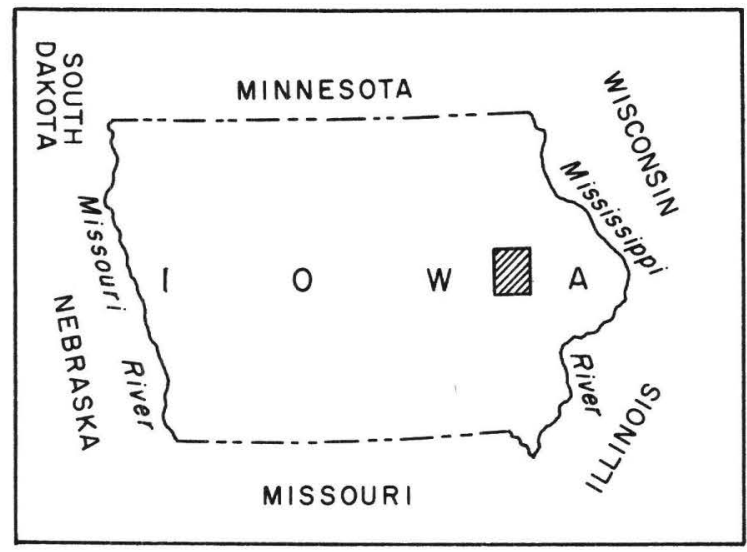

LOCATION OF LINN COUNTY

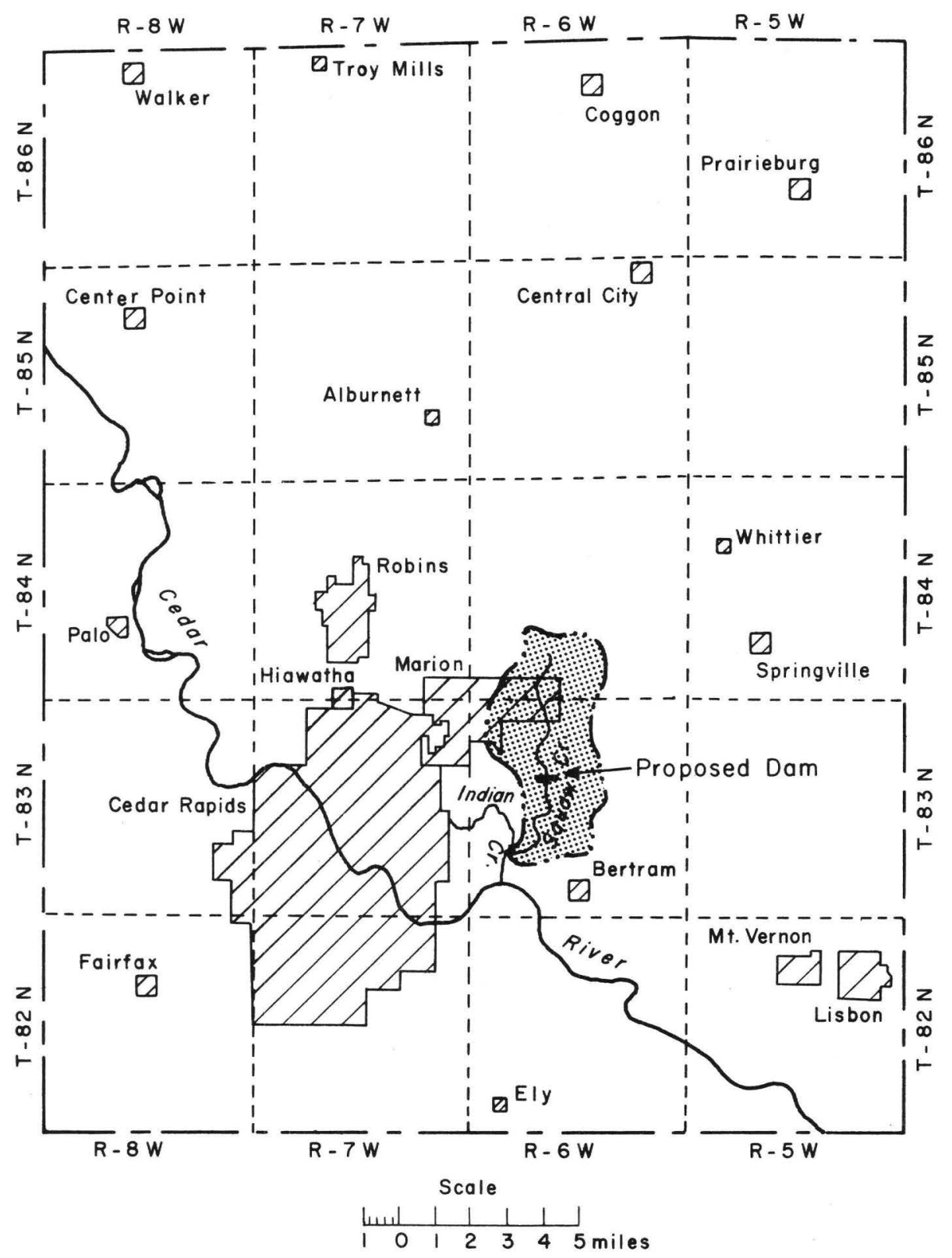

Plate 1. Map of Linn County showing location of Squaw Creek basin. 
DESCRIPTION OF THE AREA

Squaw Creek is a small stream near the eastern city limits of Cedar Rapids (pl. 1). It has a drainage area of 14.6 square miles at the mouth and empties into Indian Creek 0.85 mile upstream from the Cedar River. Most of the basin is now used for agricultural purposes. The land in the basin varies from flat to gently rolling and the creek meanders in a relatively flat flood plain. The 18,000 -foot reach covered by this report extends from the mouth of the creek to the site of a proposed recreation dam. Four bridges, including three county road bridges and one abandoned railroad bridge, span the creek in this reach.

\section{STUDY CRITERIA}

The city and State regulatory agencies requested that the inundation limits be defined by a flood of $8,000 \mathrm{cfs}$ (cubic feet per second) under present (1968) channel and valley conditions. However, in the downstream part of the reach affected by backwater from the Cedar River, they requested that an elevation of 723.7 feet above mean sea level be used as the inundation limit. This elevation corresponds to the elevation of the Corps of Engineers' standard project flood on the Cedar River at the mouth of Indian Creek (Corps of Engineers, 1.967). 
The same agencies also requested that water-surface profiles be determined for a flood of 5,600 cfs in a waterway assumed to be restricted to widths of 140 and 300 feet by encroachments. It was assumed that no flow would occur landward from the encroachment limits. It was further stipulated that in the downstream part of the reach that is affected by backwater from the Cedar River, the water surface be considered to be at elevation 718.3 feet, the elevation of the Corps of Finginoers' intermodiate regional flood on the Cedar River at the mouth of Indian Creek (Corps of Engineers, 1967). These profiles provide information that can be used in setting minimum elevations for structures that may be built on the flood plain on Squaw Creek.

As an indication of the relative magnitude of the floods selected for the study, the 50-year flood for Squaw Creek is estimated to be about 2,700 cfs. (Schwob, 1966). 
PRESENTATION OF RESULTS

Standard methods of step-backwater computation were used to define the water-surface profiles (figs. 1-4). The flood-inundation limits and restricted waterways are shown on plates 2 to 4 . Watersurface elevations and mean velocities are shown in table 1.

\section{CITED REFERENCES}

Corps of Engineers, U. S. Army, 1967, Flood-plain information, Cedar River, Linn County, Iowa: Corps of Engineers report prepared for Iową Naturäl Reșources Council,-39'p., 22 pl:

Schwob, Harlan H., 1966, Magnitude and frequency of Iowa floods: Iowa Highway Research Board Bull. 28, pt. 1, 47 p., 2 pl., 16 fgs. 
Table 1. Water-surface elevations, in feet above mean sea level, and mean velocities, in feet per second, for selected floods on Squaw Creek.

\begin{tabular}{|c|c|c|c|c|c|c|}
\hline \multirow{3}{*}{$\begin{array}{l}\text { Bistance } \\
\text { upstream } \\
\text { from mouth } \\
\text { in } 100-\mathrm{ft} \\
\text { stations }\end{array}$} & \multicolumn{2}{|c|}{ Flood of 8,000 cf's } & \multicolumn{4}{|c|}{ Flood of $5,600 \mathrm{cfs}$} \\
\hline & \multirow[b]{2}{*}{ Elev } & \multirow[b]{2}{*}{ Vel } & \multicolumn{2}{|c|}{ 140-ft waterway } & \multicolumn{2}{|c|}{ 300-ft waterway } \\
\hline & & & Elev & $\mathrm{Vel}$ & Elev & $\mathrm{Vel}$ \\
\hline 0 & a.723.7 & - & b718.3 & - & b718.3 & - \\
\hline $32+30$ & a723.? & - & b718.3 & - & b7 18.3 & - \\
\hline $32+45$ & a723.7 & - & b718.9 & 5.8 & b718.3 & - \\
\hline $37+30$ & a723.7 & - & 719.9 & - & b718.3 & - \\
\hline $39+50$ & a723.? & - & 720.5 & 5.9 & 719.2 & 5.7 \\
\hline $41+70$ & a723.7 & - & 721.1 & - & 720.1 & - \\
\hline $43+00$ & 2723.7 & - & 721.6 & 6.6 & 720.6 & $5 . ?$ \\
\hline $46+90$ & a723.? & - & 723.2 & 7.8 & 722.5 & 5.8 \\
\hline $48+30$ & a723.7 & - & 723.9 & - & 723.1 & - \\
\hline $50+70$ & 724.7 & 5.5 & 725.1 & 5.2 & 724.0 & 4.9 \\
\hline$c 54+00$ & 725.6 & 6.2 & 725.6 & 7.6 & 724.8 & 6.0 \\
\hline d $55+00$ & 729.2 & 2.6 & 730.1 & 3.0 & 729.3 & 2.4 \\
\hline $56+00$ & 729.2 & - & 730.1 & - & 729.3 & - \\
\hline $64+20$ & 729.2 & e7.9 & 720.1 & e6.9 & 729.3 & $e 6.2$ \\
\hline $65+00$ & 729.2 & - & 730.1 & - & 729.3 & - \\
\hline $66+70$ & 729.8 & - & 730.1 & - & 729.3 & - \\
\hline $67+30$ & 730.1 & - & 730.1 & - & 729.4 & - \\
\hline $78+80$ & 734.8 & 5.2 & 734.8 & $6 . ?$ & 734.0 & 4.5 \\
\hline $\begin{array}{l}87+40 \\
91+10\end{array}$ & $\begin{array}{l}737.4 \\
738.9\end{array}$ & $\begin{array}{l}7.0 \\
5.0\end{array}$ & 737.7 & $\begin{array}{l}6.4 \\
5.7\end{array}$ & 736.6 & 6.1 \\
\hline $\begin{array}{l}91+10 \\
94+90\end{array}$ & $\begin{array}{l}738.9 \\
739.8\end{array}$ & $\begin{array}{l}5.9 \\
5.4\end{array}$ & $\begin{array}{l}738.8 \\
739.3\end{array}$ & $\begin{array}{l}5.7 \\
6.0\end{array}$ & $\begin{array}{l}737.9 \\
738.7\end{array}$ & $\begin{array}{l}5.0 \\
5.1\end{array}$ \\
\hline $98+30$ & 740.4 & 5.2 & 739.9 & 6.8 & 739.2 & 5.6 \\
\hline $101+80$ & 741.4 & 5.3 & 740.9 & 7.6 & 740.5 & 4.9 \\
\hline $104+70$ & 742.1 & 6.6 & 742.0 & 7.8 & 741.2 & 6.7 \\
\hline $108+90$ & 744.0 & 7.0 & 744.1 & 7.2 & 743.3 & 6.0 \\
\hline $111+50$ & 745.1 & 8.3 & 745.1 & 7.4 & 744.2 & 7.7 \\
\hline $114+80$ & 747.2 & 5.2 & 746.4 & 7.9 & 746.2 & 5.1 \\
\hline fl119+30 & 748.4 & 5.3 & 748.4 & 7.9 & 747.6 & 6.2 \\
\hline $8120+80$ & 753.0 & $\mathrm{e} 2.3$ & 752.8 & $e^{4} .0$ & 752.6 & e2.2 \\
\hline $124+30$ & 753.0 & $\mathrm{e} 2.0$ & 752.8 & $e 4.9$ & 752.6 & e2.? \\
\hline$f 127+30$ & 753.0 & e3.6 & 752.8 & $e 6.5$ & 752.6 & e3.9 \\
\hline $8128+10$ & 753.2 & $e 2.1$ & 755.0 & e3. 5 & 753.8 & $\mathrm{e} 2.1$ \\
\hline $131+12$ & 753.2 & $\mathrm{e} 2.0$ & 755.0 & $e 4.6$ & 753.8 & e3.0 \\
\hline $137+00$ & 753.2 & - & 755.0 & - & 753.8 & $=$ \\
\hline $138+30$ & 753.6 & - & 755.0 & 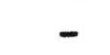 & 753.8 & - \\
\hline $140+00$ & 754.2 & - & 755.4 & & 753.8 & \\
\hline $155+00$ & 759.2 & 3.1 & 758.7 & 4.6 & 757.5 & 3.2 \\
\hline $170+00$ & 761.7 & 5.3 & 762.0 & 5.6 & 760.5 & 4.9 \\
\hline hl一 $17+50$ & 763.7 & 3.9 & 763.8 & 5.1 & 762.6 & 3.7 \\
\hline
\end{tabular}

a. Standard project flood ( $C$ of $E$ ) for Cedar River at mouth of Indian Creek.

b. Intermediate regional flood ( $C$ of $E$ ) for Cedar River at mouth of Indian Creek.

c. Downstream of Mount Vernon Road.

d. Upstream of Mount Vernon Road.

e. Affected by backwater from bridge downstream.

f. Downstream of county road.

g. Upstream of county road.

h. Site of proposed dam. 


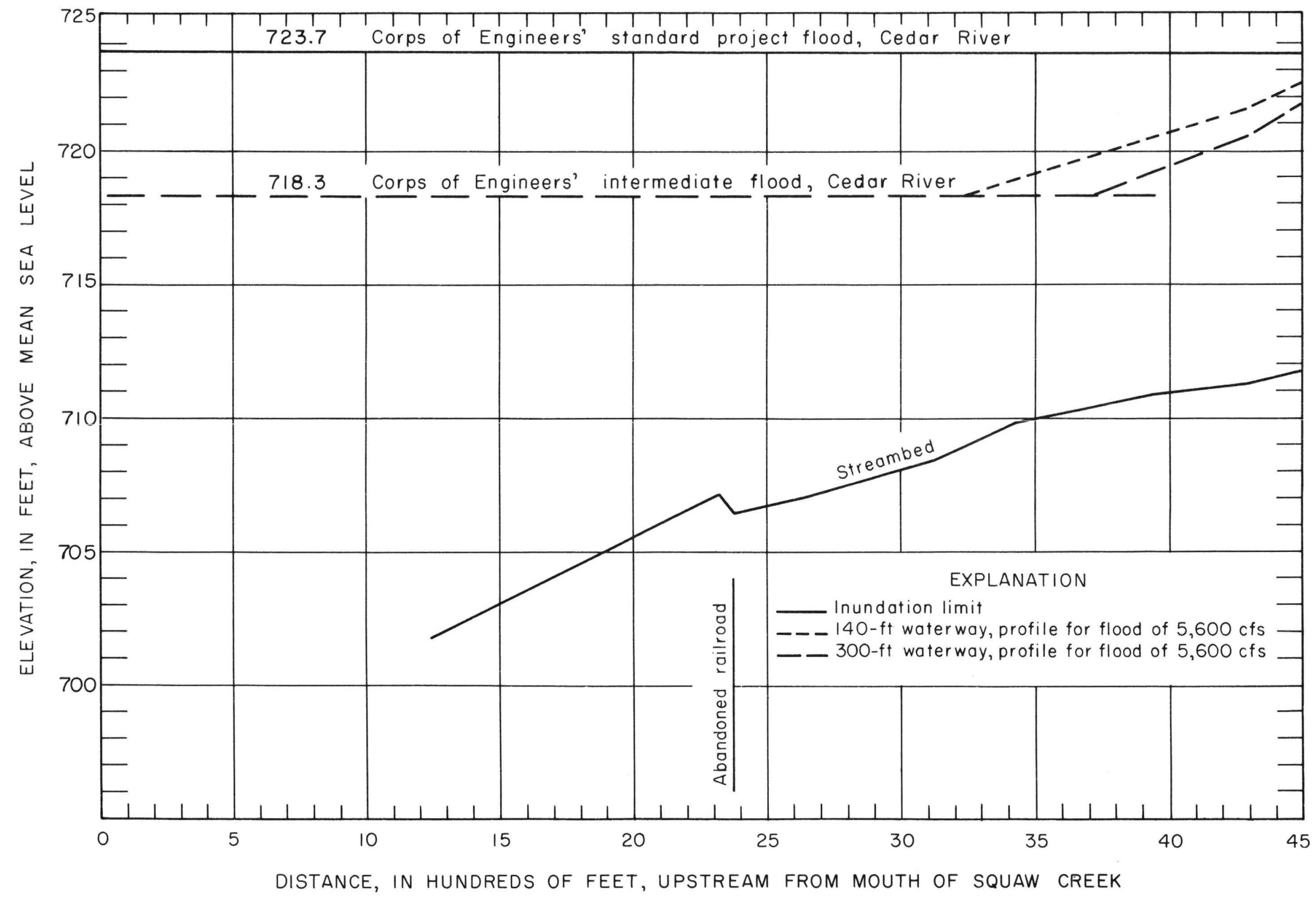

Figure 1. Flood profiles and streambed profile, mouth to station 45 , on Squaw Creek. 


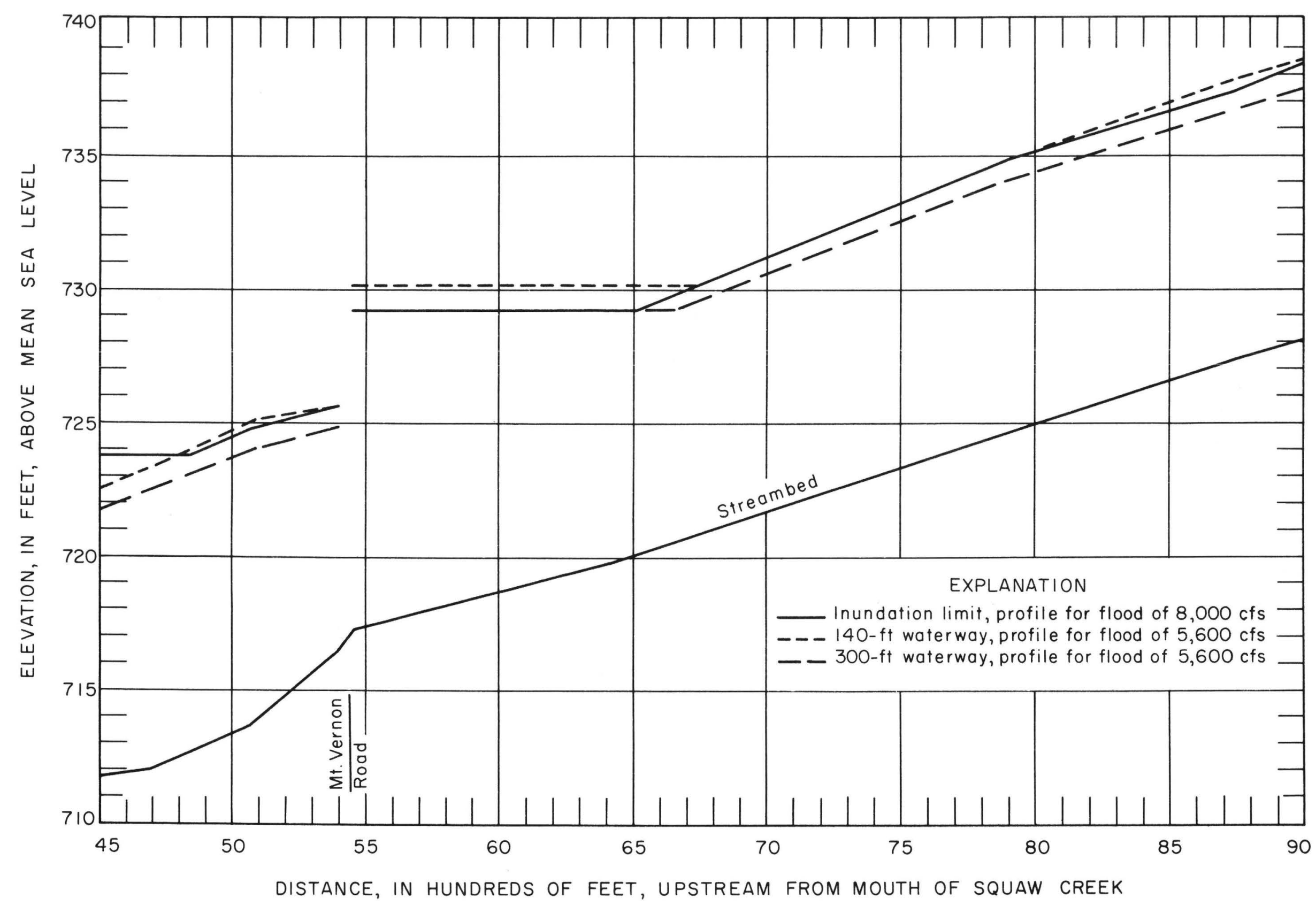

Figure 2. Flood profiles and streambed profile, station 45 to station 90 , on Squaw Creek. 


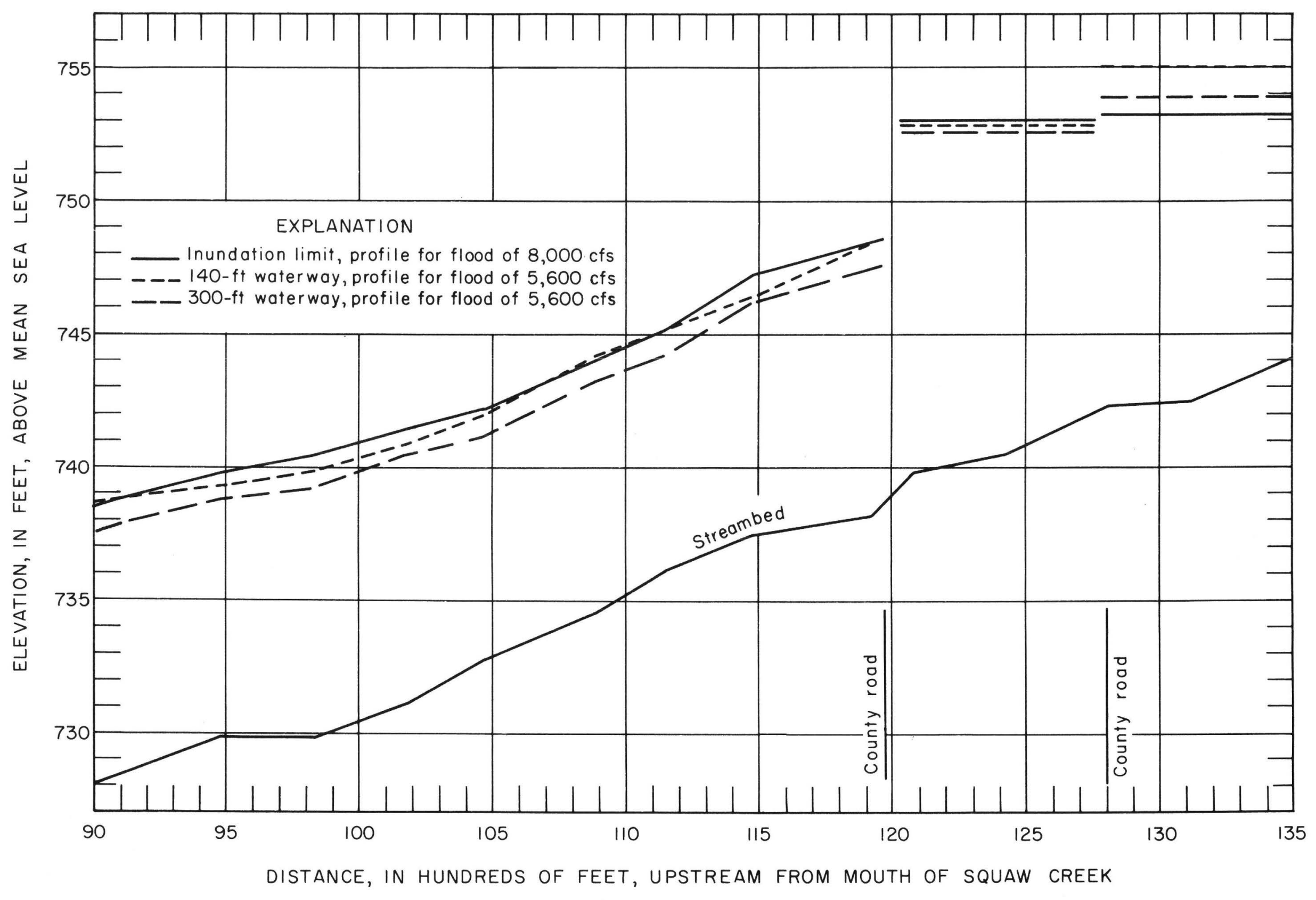

Figure 3. Flood profiles and streambed profile, station 90 to station 135 , on Squaw Creek. 


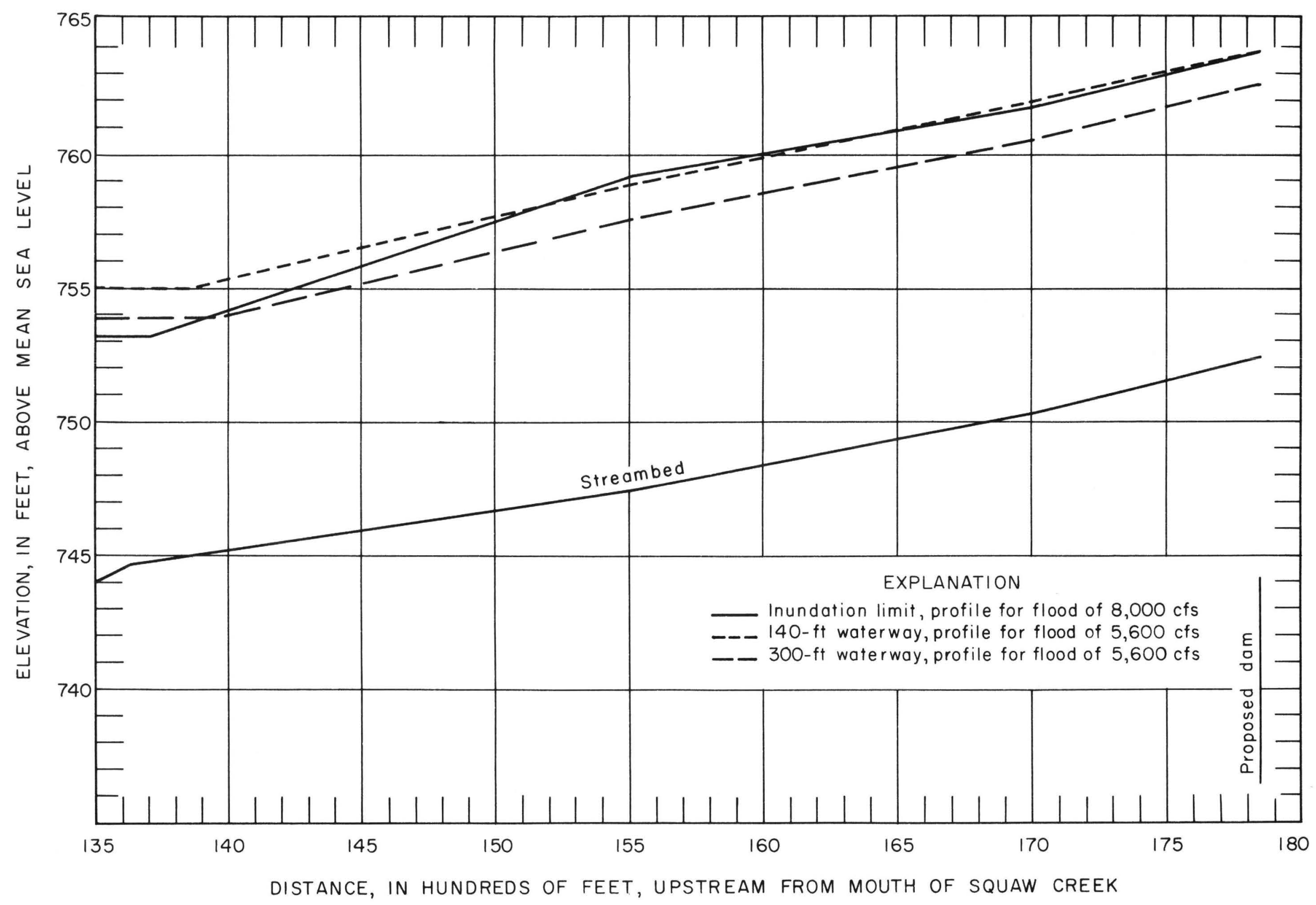

Figure 4. Flood profiles and streambed profile, station 135 to station 180, on Squaw Creek. 


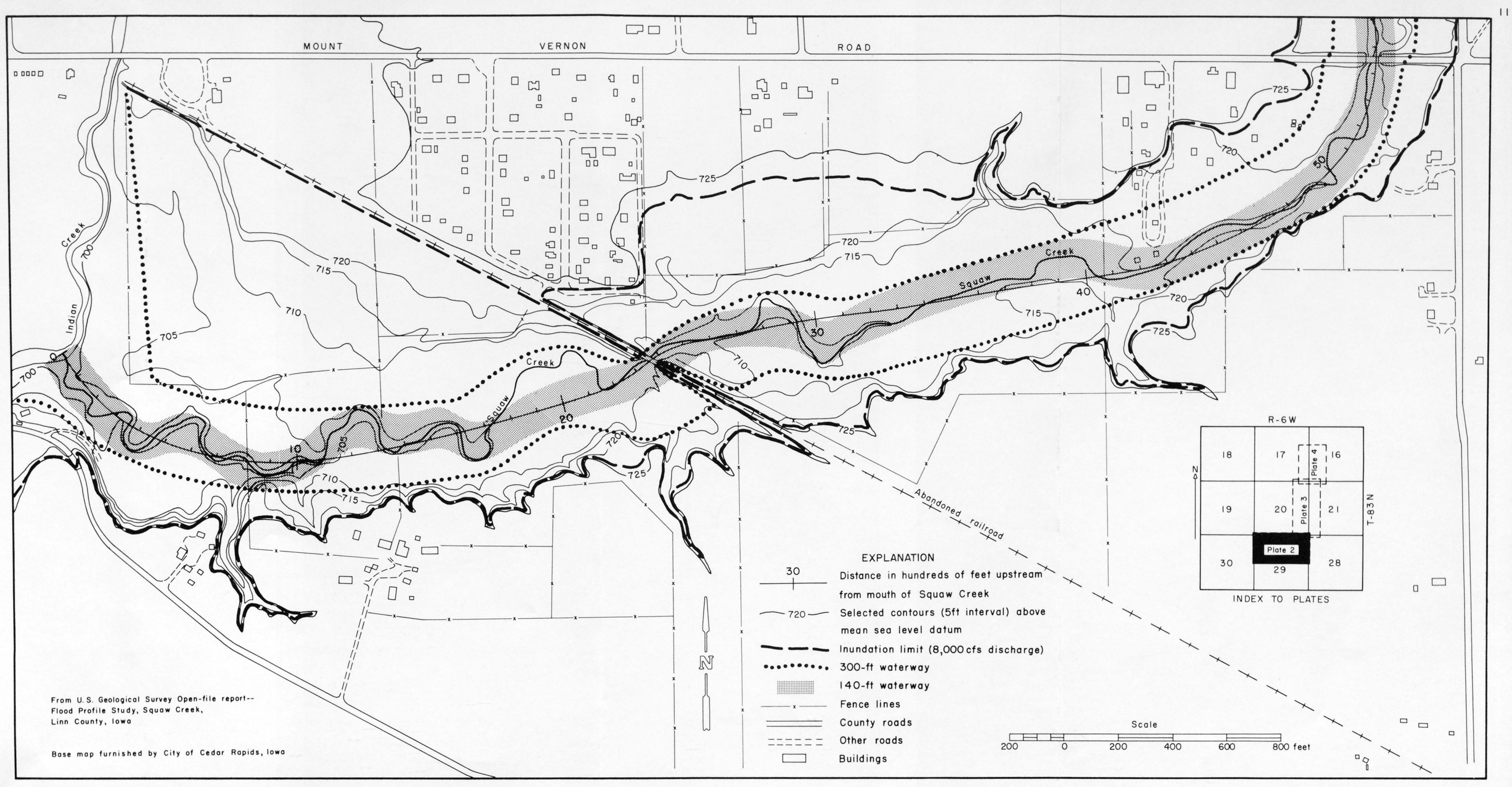




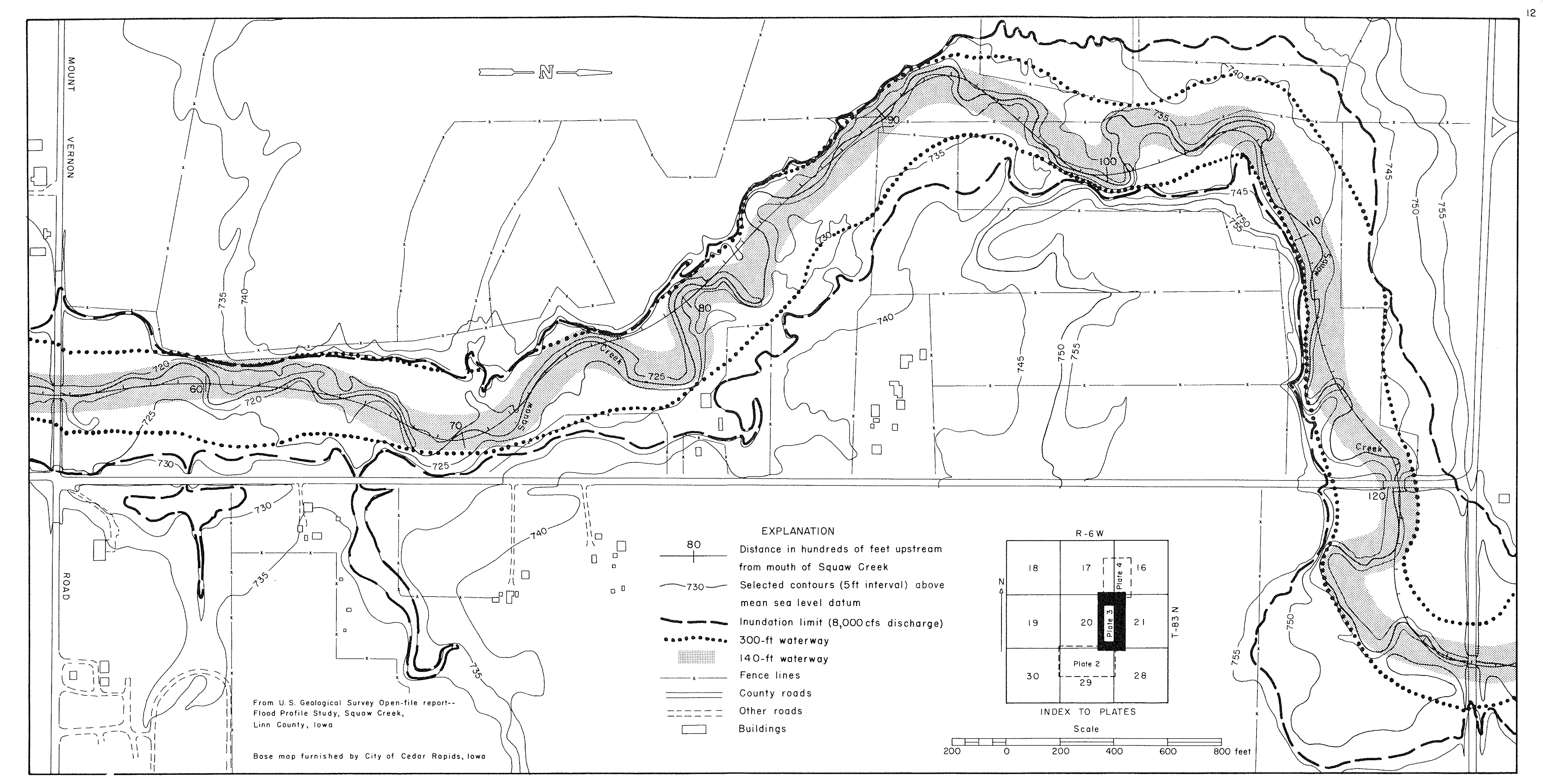




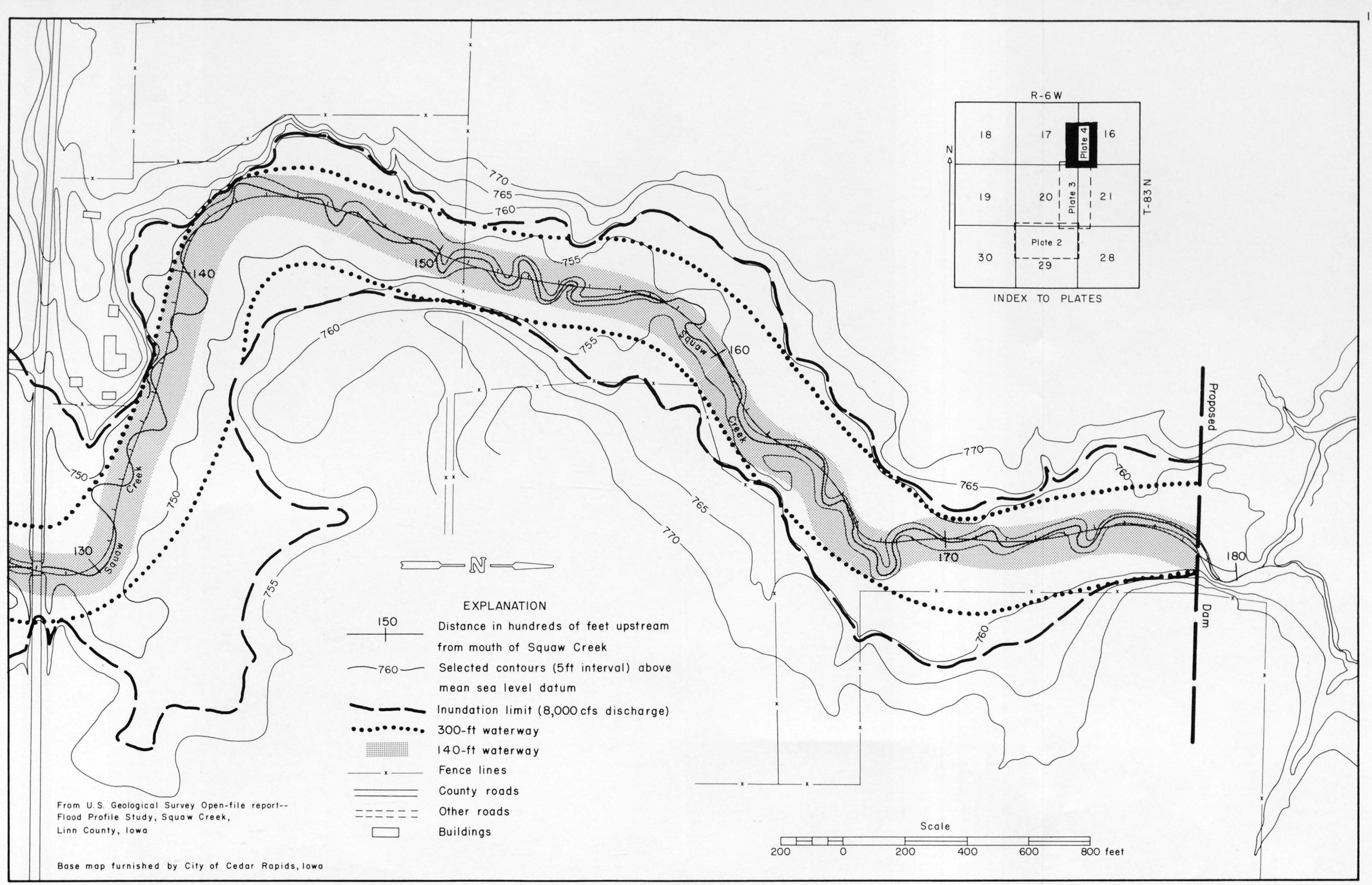

